\title{
COLLABORATIVE TEACHING CULTURES OF ENGLISH LECTURERS IN INDONESIAN POLYTECHNICS
}

\author{
Rosmaladewi Rosmaladewi \\ Victoria University Australia \& Politeknik Pertanian Negeri Pangkep Indonesia \\ Email: rosmaladewil@yahoo.com \\ Amirullah Abduh \\ Universitas Negeri Makassar, Indonesia \\ Email:amirullah@unm.ac.id
}

\begin{abstract}
This paper aims to explore collaborative culture in three polytechnics in South Sulawesi. This study applied an interpretive qualitative case study of nine English lecturers using interviews, documents and observations. Drawing from Hargreaves and Fullan's (2012) collaborative cultural concept, this study finds that contrived collegiality is more dominance rather than genuine collaborative learning culture. This finding suggests that collaborative culture is structured formally and bureaucratically. This impact on the way lecturers perform their teaching, norms and their values.
\end{abstract}

Key words: collaborative, culture, polytechnics, Indonesia, South Sulawesi

\section{INTRODUCTION}

Studies on collaborative cultures are considered as an important feature of a learning organisation. As Hargreaves (1994) argues that collaborative culture is important for educators because they can learn from one in another. Similarly, Kennedy (2003) suggests that establishing collaborative culture help both people to grow professionally and organisation as learning organisation. Working together can reduce burden of working load and help educators establishing both professional and social networks (Hargreaves \& Fullan, 2012). Those authors indicate the importance of collaborative cultures in organisations.

In Indonesian contexts, research into collaborative cultures has mainly focused on teachers collaborative works on lesson study (Saito, Harun, Kuboki, \& Tachibana, 2006), partnership between schools and universities, (Saito, Harun, Kuboki, \& Tachibana, 2007), professional development of teachers (Firman \& Tola, 2008). These studies indicate that collaborative teaching cultures remain unexplored. This study addresses this gap, particularly investigating collaborative cultures in polytechnics.

Polytechnic is a vocational higher education, which caters for a combination of knowledge and applied skills from Diploma I to Diploma IV programs (Law of Education No.20 2003). Recently, Diploma IV programs have been equated to Bachelor degree status in the Indonesian education system. Graduates from these programs can now hold an Applied Bachelor degree (Peraturan Pemerintah [Government Regulation] No 17, 2010). Polytechnics can also offer professional masters and doctorates which specialise in certain disciplines. For example, in our informal observation, the Master of Applied Electrical Engineering in Surabaya State Polytechnic became the first professional graduate degree offered at a polytechnic.

As a result of the recent reforms within Indonesia, the polytechnic has experienced 
significant changes in its roles as it can now offer degrees similar to those offered at universities and is therefore in direct competition. Such reforms have brought about considerable change and for lecturers, change is particularly evident in the areas of workload and related roles and responsibilities. This inevitably may impact on the culture of teaching within polytechnics.

\section{COLLABORATIVE CULTURES}

We will focus on teaching cultures that have been introduced by Hargreaves (1994): Individualism, balkanisation, contrived collegiality, and collaborative cultures. Then, Hargreaves and Fullan (2012) revisited these teaching cultures and regroup them into two major types: individualism and collaborative cultures. It can be understood that balkanization, contrived collegiality, and collaborative culture focus one similar idea which is to work together and to learn from other. However, they have different characteristics, which differentiate them from individualism.

On the other hand, collaborative cultures consist of four types: balkanisation, contrived collegiality, professional learning communities, and network and federation (Hargreaves \& Fullan, 2012):

Balkanisation cultures made up of separate and sometimes competing groups.... Contrived Collegiality is characterized by formal, specific bureaucratic procedures to increase the attention being given to join teacher planning and other forms of working together.... Professional learning communities is continuing groups and relationships committed to and have collective responsibility for a common educational purpose, committed to improving their practice in relation to that purpose, and committed to respecting and caring for each others' lives and dignity as professionals and people....Network and federation relates to teachers learn from others within their teams and schools, they learn even more from collaboration among institutions (Hargreaves \& Fullan, 2012, pp. 107-108).

Hargreaves defines that the culture of collaboration and contrived collegiality are similar in terms of teachers work together, support each other, mutual understanding, and openness to discuss and to solve the problems they encounter. In this sense, collaboration and contrived collegiality are "seen as forming vital bridges between school improvement and teachers development (1994b, p. 186). However, collaborative cultures and contrived collegiality have different characteristics in a way they are developed and implemented by teachers, as shown in (See Table 1) below.

Table 1. Collaborative culture and contrived collegiality (Hargreaves, 1994, pp. 192-196).

\begin{tabular}{|c|c|}
\hline Collaborative & Contrived Collegiality \\
\hline Spontaneous & $\begin{array}{l}\text { Administratively } \\
\text { regulated }\end{array}$ \\
\hline Voluntary & Compulsory \\
\hline $\begin{array}{l}\text { Development- } \\
\text { oriented }\end{array}$ & Implementation-oriented \\
\hline $\begin{array}{l}\text { Pervasive across } \\
\text { time and space }\end{array}$ & Fixed in time and space \\
\hline $\begin{array}{l}\text { Unpredictable } \\
\text { outcome }\end{array}$ & Predictable outcome \\
\hline
\end{tabular}

Collaborative culture has numerous the advantages for teachers. Jarzabkowski points out that 'working collaboratively saves teachers time, inspires better teaching, and improves the quality of teaching practice by creating better ideas for and about teaching' (1999, p. 13). Working collaboratively can be in the form of informal conversation, which then enhances the team-building and ongoing development for a school (William, 
2001). Brady and Kennedy (2003, pp. 312313 ) identifies that collaborative culture can promote opportunities to learn, foster continues school development and create professional confidence.

Recent study by Virta (2015) in Finnish educational contexts and suggested that teachers are no longer work individually, they more work together with other teachers, work with administrative staff, and corporate with parents. Virta claimed that teachers work together in different levels of combinations beginning from the same department to teachers from other schools. I assume, Virta's (2015) research can be very acceptable if institutions are inclusive and are aware of the importance of working collaboratively. For some institutions where competition culture is high, collaborative culture becomes utopia, which is only in imagination.

The other recent study by Martin and Dismuke (2015) indicated that collaborative culture can occur especially for teachers' candidate including: "1) development of course content across an array of activity settings, (2) working in small group and partner settings, and (3) immersion in experiential activity as both teacher and writer (p. 109). Collaborative cultures can considered as part of part of creating learning communities, service and community-based learning, and interdisciplinary research and teaching (Kanter, 1994; Kezar, 2005; Senge, 1997). Kezar (2005) suggested that collaboration enhances greater efficiency, effectiveness, and perhaps most importantly for higher education institutions, it has been claimed that collaboration enhances students' learning. Similarly, Bakken, Clark, Thompson, and Thompson (1998) investigated the benefit of working in a team. They revealed that working in team has benefit to both teachers and students. For teachers, it increases teachers' patience and tolerance, and for students, it offers students various perspectives from different teachers. Further, Nevin, Thousand, and Villa (2009) reported that collaborative teaching offers teacher educators models to compare and contrast with their own experiences.

One of the challenges in implementing collaborative teaching culture is aging infrastructure. Kustra et al. (2015) commented that the lack of supporting infrastructure such as limited technology to support teaching and limited spaces for cooperation, becomes constraints in realizing quality teaching cultures. Kustra et al. (2015) recommended that raising awareness of quality teaching has long positive impact on students learning and outcome. In addition, Watson and Widin (2014) identified the attitudes of teacher to reject change is another constraint. Some teachers prefer to maintain status quo because they feel comfortable with their existing practices, even though they attend professional training programs.

It is interesting to note that teaching cultures either individualism or collaborative cultures can both impact on teaching and learning. For some teachers who prefer to work individually, they may be difficult to work in small or larger group. On the other hand, working collaboratively may not benefit all teachers because there may be possibilities of some teachers dominate others.

\section{METHODOLOGY}

An interpretive qualitative case study was applied in this research. An interpretive case study was appropriate when drawing specific implication of the research (Walsham, 1995). This study has particular implications for lecturers who teach in Indonesian polytechnics particularly in South Sulawesi contexts. This study employed semi-structured interviews of nine lecturers of English in three polytechnics. The semistructure interviews were conducted in Indonesia that lasts between 45 minutes and 
1 hour. Of the nine participants, 6 were females and 3 were males. Their ages range between 35 and 45 years old. Data were analysed using thematic analysis procedures (Braun \& Clarke, 2006): reading whole data, identifying themes, classifying themes, and identifying core themes.

\section{FINDINGS}

Collaborative cultures of English lecturers from Polytechnic A, B \& C are described as follows.

\section{Polytechnic A}

From lecturer participants, in terms of teaching, the most common ways of performing teaching tasks is through structural team appointment and voluntarily team-teaching groups. It was reflected by a participating senior lecturer: "Successful teaching English is not an individual job. We must work together not only for teaching but also for completing a book project" (L1.A). Lecturers view team-work is an efficient and effective strategy in planning, teaching and assessment. It is their belief that team-work is a step to successful delivering teaching task.

The structural team-teaching tasks are appointed by senior management for certain subjects. It is explained by one senior lecturer: "I got a mandate as an English coordinator ... to work with lecturers in English team" (L1.A). The number of team members varies according to the tasks, and subjects to be delivered. It is normally between four to six people in one team members. It is explained by junior lecturer: "We are totally four members in English team at this moment.... I handle some classes with two other lecturers" (L3.A). While another senior lecturer supported: "We used to have 6 members of English team so it was easier to replace each other" (L2.A)

They established all required documents to assist them for teaching delivery modes including planning, observing, implementing, monitoring, evaluating and assessing subjects. It is supported by a senior lecturer:

I am one of the team members. A kind of team teaching because we teach in a team, two to three lecturers in a small team.... We are team in all activities I can say, from planning, designing books, teaching even though we teach different topics, and evaluation. All lecturers have to prepare question sheets for final examination. (L2.A)

There are several criteria that consider putting in place when forming team-teaching. They are experiences, skill and knowledge expertise to the subject in Sehat. It is described by an English coordinator:

Team is divided based on their knowledge and skill.... When we conducted English course for all academic staff and leaders, one junior lecturer (who is not major in English) but seems had good English so I offered her to join our English team, and she likes it. Now she is experienced as she has handled English classes for some semesters (L1.A)

Besides, the other important criteria to be included in a team member are educational backgrounds. The senior managers normally consider whether they are domestic or overseas graduates. It is expressed by senior lecturer: "I have been involved in English (teaching) team since I completed my Masters in Australia" (L2. A). Another junior lecturer supported:" Even though I consider my English is poor but I learn much from my team, especially Australia university alumni" (L3. A). The senior managers place equally overseas graduates in every team work because of international experiences they had.

Through team teaching, lecturers distribute the tasks equally amongst their team. In each task they assign one lecturer to be responsible for the implementation. For example, there is one team member organising references for 
teaching materials, as pointed by a senior lecturer coordinator:

"I am in charge to design the reference (handbooks) that we will use at least for one level (year), but I need other lecturers to help me, that is why I asked her who has very good English for helping me. Other team members also helped me including ideas in teaching approach" (L1.A.).

It is also in the context of preparing teaching materials as most participating senior and junior lecturer explained: “...we can talk in our team who can replace them to handle every chapter in our handbook" (L2.A) and "We create (wrote) this book together" (L1.A), as well as "I helped, creating this book even only copied additional material to put in this book" (L3.A). Also there is a team coordinator who controls and manages the implementation of team-teaching tasks, as elucidated by one participating senior lecturer:

Besides as a member in English team, I am also a coordinator in other unit. As a coordinator I am responsible to control the unit and team, while as a member in English team I can say I have to listen to English coordinator including design English handbook with him (L2.A)

In terms of voluntary work among team member, each member is not obligatory to replace other team member when they are absent. The example of replacement in teaching tasks, as indicated by a participant: "One of English teams now is studying so she is not very active and we must understand if sometimes we need to replace her class" (L1.A). It is a kind of voluntary initiative among team members.

In addition, researching and community services are also done in a team. The reason for this is that they are easier to complete tasks on time because they have described job description of each team member prior to task implementation. It is explained by one participant: We must complete teaching, research, and community services together
(L1.A). It is supported by the other respondent:

"It must be completed, not only teaching load but also research, community services and additional or extra activities. That's why we have to share and work together. Conducting Research then publish paper in journal is very important at this moment...easier when we do it in team" (L2.A)

They also easier to replace one in another in a team, as highlighted by other participant: "...meeting only between the team members.... We adjust what module or chapter that we want, and we adjust our schedule with other activities "(L3.A). This shows that lecturers have been successful in performing their work through their team.

However, lecturers also face a difficulty in terms of choosing a priority and communication. Lecturer participants find it hard to prioritise one task when a lot of important tasks occurring at the same time. The unit coordinator, for example, faces a dilemma in decision making when performing two roles at the same time. He found it hard to insist other people do things, because he is also part of the group. It is expressed by a senior lecturer: "I am one of the English team in teaching, while as coordinator in other unit/subject.... Sometimes these different positions are confusing" (L2.A). The position makes him/her in difficult situation to juggle his/her schedule and task.

The other challenge is that communication problems. It became concerned of one participant: "I have difficulties (in teaching).... I can say communication is very important so our team can understand our problems (in teaching and personal problems)" (L3.A). It is often among team member to miss-understanding each other's due to communication problems. 


\section{Polytechnic B}

Both manager and lecturer participants in this study expressed that team teaching was a common way of performing multiple roles.

With regards to managers' perceptions, working in a team was required to support each other. This signals that a team was formed by a leader. One participating leader mentioned: "Team works were done through sharing classes, teaching materials, assisting extra classes, research activities, and community services" (H1.B). In addition, the other leader commented: "We usually work together to apply for grants either from the institution or higher level research grants from the Higher Education and Transportation Ministries" (H2.B). This indicates that a structural team was formed by their leaders and was a dominant way of performing roles in this polytechnic.

With regards to lecturers' views, peer or team teaching was not only an instruction from our leaders but more as a system for performing tasks Ikan. It included in the area of teaching, research and community services. In terms of teaching, one English lecturer commented:

There must be mutual understanding that we need those seamen in terms of teaching English related to Maritime. Conversely, they need us (English lecturers whose educational background is English) in terms of the English knowledge itself such as grammar. So in teaching English we are teamed with seamen lecturers who can speak English and have spent time in a boat with foreign seamen (L3.B)

The other English lecturer indicated team teaching was done in order to be able to support each other: "One lecturer can swap or replace another lecturer when he/she is not available to teach" (L2.B). In relation to research, a team was formed to apply local and national grants. One participating lecturer stated: "applying for research grants from external sources such as the central government through the Ministry of Transportation or through the Ministry of Education is usually done in teams" (L1.B). In relation to community service activities, one lecturer participant explained: "It is a part of the institution policy where any activities relating to the community should be done in teams for effectiveness" (L1.B). This indicates that performing academic roles was done in teams. Thus this team was structurally established.

It appears that lecturers performed multiple roles either as academics and administrative staff. Their commitment, cultural and religion factors become the underpinning factors of lecturers performing multiple roles. It may be important to train administrative staff for a leader position of administration.

\section{Polytechnic C}

Both participants (managers and lecturers) argued that working in a team was a common culture in this polytechnic. This section describes working in a team and reasons of choosing it.

From managers' perspectives, lecturers mostly worked in team rather than solo. Working in teams was done such as in the area of teaching, research, and completing training programs. One participating manager commented that "we organised lecturers to work in team, in teaching, research and training programs" (H1.C). A team may consist of two or three lecturers depending on the job assigned to lecturers. For example, teaching can include "two or three lecturers in a group" (H1.C). The reason of working in team was due to the flexibility for swapping schedule: "If one of them is absent or unable to perform their duties, the other can replace it" (H2.C). Therefore, working in a team was a common teaching culture in this polytechnic. 
From lecturers' perspectives, lecturers worked in a team both for teaching and delivering training programs. The training programs included a short training for industry preparation placement. One English lecturer participant stated that "there are many training programs which need a team or committee to complete the task at a short notice and for a short period of time" (L3.C). The team usually consisted of senior and junior lecturers. The other English lecturer participant commented: "I always teach in team especially as I am a junior lecturer to learn from the seniors" (L1.C). It might include "two senior lecturers and one junior lecturer or vice versa two junior lecturers and one senior lecturer" (L2.C). This highlights the team was the prefer way of conducting activities in this polytechnic.

Lecturers described the main reasons of working were to be able to help each other, to learn from others, and to familiarise with new environment. One English lecturer participant delineated that "in my department I have team teaching so that we help each other to teach across departments" (L3.C). In addition, working in a team might help new lecturers to familiarize with the new environment because "new lecturers can learn from senior ones" (L2.C). Moreover, working in a team provided the opportunity for new lecturers to get involved in institutional activities academically so that they can feel welcome and can adjust the situation. One English lecturer stated: "leader and senior colleagues think that we need additional various activities to help understand the organisational lives, maybe that's why we are often in teams" (L1.C). Therefore, working in a team can facilitate junior to learn from seniors and to familiarise new lecturers with the environment.

It seems that working in a team was a prefer way of performing academic and nonacademic tasks in Mesin. Working in a team offered a way of transferring knowledge from seniors to juniors and a way to participate and familiarise with the new environment.

\section{DISCUSSION}

A team teaching identified as a model of teaching mode within these three polytechnics. This section discusses the essential characteristics and benefits of team teaching. This contributes to add new understanding of Hargreaves (1994) and Hargreaves and Fullan (2012) of contrived collegiality and collaborative teaching cultures.

The findings reveal that the characteristic of team teaching is considered the transition between contrived collegiality and collaborative teaching cultures. This is due to team-teaching possessing elements of the two types of teaching cultures. In relation to contrived collegiality, team teaching is similar to Hargreaves and Fullan (2012) that formally constructed by leaders and follow bureaucratic procedures, as it is found in Ikan and Sehat. Team teaching is also constructed voluntarily by lecturers as it is done in Mesin and Sehat, which is a reflection of Hargreaves and Fullan (2012) collaborative culture.

There are advantages and drawback of this transitional model between contrived collegiality and collaborative teaching cultures. The benefits of this model are similar to some elements of earlier studies include learning from colleagues, respect each other complement each other (Hargreaves, 1994; Hargreaves \& Fullan, 2012), and increase bonds among team members (Bolman \& Deal, 2008). In addition, each lecturer brought their own knowledge, experience and personal values that had to be developed into making a cohesive team(s). However, the potential drawback of this transitional model of team teaching is that the lack of flexibility due to the standardised roles and responsibilities imposed senior administration. In addition, 
different lecturers' teaching approaches applied could lead to confusion for some students.

The implications of this transitional model are working collaboratively either voluntarily and structurally can be considered as the norms of team teaching in these polytechnics. Firstly, lecturers are encouraged to learn and make use of the team in order to benefit students. Secondly, lecturers are required to be more tolerance to each other. Finally, lecturers are encouraged to sacrifice their time and energy in order to achieve team's goals.

\section{CONCLUSION}

Team-teaching is the most common type of teaching culture. This type of teaching culture reflects Hargraves' and Fullan's (2012) contrived collegiality teaching culture. The contrived collegiality refers to structural collaboration. Thus structural collaboration is viewed as the team teaching is constructed by leaders based on specialisation. In order to implement the mandate of the leaders, it is important to administratively regulate the task of the lecturers. This regulation is similar to what Hargreaves (1994) describes as team that is administratively regulated, implementation oriented and fixed time and space. This indicates that structural team-teaching is a compulsory team that is formed by leaders.

The implication is that the practice of contrived (structural) collegiality can disadvantage lecturers' creativity. The lecturers can only work on a certain task based on the specific job that is stipulated in the instructional letter, and very often lecturers have less initiative to start the job because they waited for orders letter from their leaders. Therefore, a spontaneous or a genuine collaboration is important to establish among lecturers so that they can work together based on their similar interests and goals.

\section{ACKNOWLEDGEMENT}

Thank you very much for Bill Eckersley and Anna Popova, who provides suggestions and feedback for the improvement of this article.

\section{REFERENCES}

Bakken, L., Clark, F. L., Thompson, J., \& Thompson, J. (1998). Collaborative teaching: Many joys, some surprises, and a few worms. College Teaching, 46(4), 154-157.

Bolman, L. G., \& Deal, T. E. (2008). Reframing organizations: artistry, choice, and leadership. San Francisco: Jossey-Bass.

Braun, V., \& Clarke, V. (2006). Using thematic analysis in psychology.Qualitative research in psychology, 3(2), 77-101.

Hargreaves, A. (1994). Changing teachers, changing times: Teachers' work and culture in the postmodern age. New York: Teachers College Press.

Hargreaves, A., \& Fullan, M. (2012). Professional capital: Transforming teaching in every school: Teachers College Press.

Kanter, R. M. (1994). Collaborative advantage: the art of alliances. Harvard business review, 72(4), 96-108.

Kezar, A. (2005). Redesigning for collaboration within higher education institutions: An exploration into the developmental process. Research in Higher Education, 46(7), 831-860.

Kustra, E., Doci, F., Gillard, K., Hondzel, C. D., Goff, L., Gabay, D., . . . Ellis, D. (2015). Teaching Culture Perception: Documenting and Transforming Institutional Teaching Cultures. Collected Essays on Learning and Teaching, 8, 231-244.

Martin, S. D., \& Dismuke, S. (2015). Teacher candidates' perceptions of their learning and engagement in a writing methods 
course. Teaching and Teacher Education, 46, 104-114. doi: http://dx.doi.org/10.1016/j.tate.2014.11. 002

Nevin, A. I., Thousand, J. S., \& Villa, R. A. (2009). Collaborative teaching for teacher educators-What does the research say? Teaching and Teacher Education, 25(4), 569-574.

Peraturan Pemerintah [Government Regulation] No 17. (2010). Pengelolaan dan Penyelenggaraan Pendidikan. Jakarta: Kementerian Pendidikan Nasional.

Saito, E., Harun, I., Kuboki, I., \& Tachibana, H. (2006). Indonesian lesson study in practice: Case study of Indonesian mathematics and science teacher education project. Journal of In-service Education, 32(2), 171-184.

Saito, E., Imansyah, H., Kubok, I., \& Hendayana, S. (2007). A study of the partnership between schools and universities to improve science and mathematics education in Indonesia. International Journal of Educational Development, 27(2), 194204.

Senge, P. M. (1997). The fifth discipline. Measuring Business Excellence, 1(3), 46-51.

Firman, H., \& Tola, B. (2008). The future of schooling in Indonesia. Journal of International Cooperation in Education, 11(1), 71-84.

Virta, A. (2015). "In the middle of a pedagogical triangle"-Native-language support teachers constructing their identity in a new context. Teaching and Teacher Education, 46, 84-93.

Walsham, G. (1995). Interpretive case studies in IS research: nature and method. European Journal of information systems, 4(2), 74-8 